\title{
Cervical Intraepithelial Neoplasia in a Cohort of HIV-positive Women at the University Hospital of the West Indies: Management and Outcome
}

\author{
I Bambury ${ }^{1}$, A Mullings ${ }^{1}$, H Fletcher ${ }^{1}$, N Johnson ${ }^{1}$, M Tulloch-Reid ${ }^{2}$
}

\begin{abstract}
Objective: To determine the rate of recurrence of cervical intraepithelial neoplasia (CIN) in HIVpositive women evaluated at the University Hospital of the West Indies (UHWI).

Method: A chart review of all non-pregnant HIV-positive women who attended the gynaecologic and colposcopic clinics between January 1994 and December 2004 identified 21 such women. Fifteen of these patients who had CIN and had at least one follow-up Pap smear were the main subjects of this study. These patients were compared to 21 HIV-negative controls who were seen during the same period and who also had at least one follow-up Pap smear. Treatment modalities for the groups included cold coagulation and large loop excision of the transformation zone (LLETZ). Cox proportional hazards analysis was used to determine the effect of HIV status on the time to first recurrence of CIN.

Results: The mean ages of the subjects were $32.7 \pm 8.0$ and $33.2 \pm 8.1$ years, respectively. With a mean follow-up period of 1.7 years, the rate of recurrence of CIN in patients with and without HIV was 66.24 $(95 \%$ CI 27.6, 159.1) and $3.0(95 \%$ CI 1.3, 7.3) per 100 person years. The hazards rate ratio for recurrence in subjects with HIV after adjusting for age and CIN stage was 19.1 (95\% CI 4.4, 82.1). Conclusion: HIV increases the risk of recurrence of CIN.
\end{abstract}

Keywords: Cervical cancer, cervical intraepithelial neoplasia, HIV

\section{Neoplasia Intraepitelial Cervical en una Cohorte de Mujeres VIH-positivas en el Hospital Universitario de West Indies: Manejo y Resultados}

\author{
I Bambury ${ }^{1}$, A Mullings ${ }^{1}$, H Fletcher ${ }^{1}$, N Johnson ${ }^{1}$, M Tulloch-Reid ${ }^{2}$
}

\begin{abstract}
RESUMEN
Objetivo: Determinar la tasa de recurrencia de la neoplasia intraepitelial cervical (NIC) en las mujeres VIH-positivas evaluadas en el Hospital Universitario de West Indies (HUWI).

Método: Una revisión de las historias clínicas de todas las mujeres VIH-positivas no embarazadas que asistieron a la clínica ginecológica y la clínica colposcópica entre enero de 1994 y diciembre de 2004, identificó 21 de estas mujeres. Quince de estas pacientes que tenían NIC y habían tenido al menos una prueba de Papanicolaou de seguimiento, fueron los sujetos principales de este estudio. Estas pacientes fueron comparadas con 21 controles de VIH-negativos que fueron vistos durante el mismo periodo y que también tuvieron al menos una prueba de Papanicolaou de seguimiento. Las modalidades de tratamiento para los grupos incluyeron coagulación fría y escisión con asa grande de la zona de transformación (LLETZ). El modelo de análisis de riesgos proporcionales de Cox fue utilizado para determinar el efecto del estatus de VIH al momento de la primera recurrencia de CIN.

Resultados: Las edades promedios de los sujetos fueron $32.7 \pm 8.0$ y $33.2 \pm 8.1$ años, respectivamente. Con un periodo de seguimiento promedio de 1.7 años, la tasa de recurrencia de NIC en pacientes con y sin VIH fue 66.24 (95\% IC 27.6, 159.1) y $3.0(95 \%$ IC 1.3, 7.3) por 100 personalaños. El cociente de tasas de riesgo de recurrencia en pacientes con VIH después de ajustar por edad y etapa de CIN fue 19.1 (95\% IC 4.4, 82.1).

Conclusión: El VIH aumenta el riesgo de recurrencia de la NIC.
\end{abstract}

From: ${ }^{1}$ Department of Obstetrics and Gynaecology, Faculty of Medical Sciences and ${ }^{2}$ Tropical Medicine Research Institute, The University of the West Indies, Kingston 7, Jamaica.
Correspondence: Dr I Bambury, Department of Obstetrics and Gynaecology, Faculty of Medical Sciences, The University of the West Indies, Kingston 7, Jamaica. E-mail: ianbam12@hotmail.com 
Palabras claves: Cáncer de cuello uterino, neoplasia intraepitelial cervical, VIH

West Indian Med J 2013; 62 (4): 314

\section{INTRODUCTION}

Women infected with HIV are at increased risk of developing pre-invasive cervical lesions and invasive cervical cancer (1) and they may have higher grades of cervical intraepithelial neoplasia (CIN) than HIV-negative women. As a result, in 1993, invasive cervical cancer was designated an AIDSdefining disorder by the US Centers for Disease Control and Prevention (2). The treatment of pre-invasive cervical disease in HIV-infected women is among the most challenging and frustrating tasks, as they often experience higher rates of recurrence (3).

\section{OBJECTIVE}

The objective of this study was to review the presentation, risk factors, treatment and rate of recurrence of CIN in HIVpositive women evaluated at the University Hospital of the West Indies (UHWI) colposcopic unit and gynaecology clinic, and to compare them with a group of HIV-negative women.

\section{SUBJECTS AND METHOD}

Charts for all non-pregnant female patients with HIV treated at the UHWI colposcopy clinic from 1994 to 2004 with cervical abnormalities were reviewed. For each subject, demographic data, social and sexual history, time of diagnosis of HIV, gynaecologic presentation for Pap smear, time of diagnosis of cervical abnormalities, presence of human papillomavirus virus (HPV) infection, use of antiretroviral therapy and CD4 counts were extracted.

Twenty-one HIV-positive women were identified; 15 of these patients were seen for cervical disorders and were the focus of this paper. These patients were matched according to stage of CIN, age and, when possible, parity, to women who were HIV negative. HIV infection was defined serologically from enzyme-linked immunosorbent assay (ELISA) and Western blot tests criteria (4). Cervical intraepithelial neoplasia and invasive cervical lesion were diagnosed by colposcopic biopsy and histology. Recurrence of CIN was determined by follow-up Pap smears and defined as low-grade or high-grade using the Bethesda System of Classification.

\section{Statistical analysis}

Statistical analysis was performed using Stata 8. Proportional hazards models were used to determine the effect of HIV status on the risk of recurrence of cervical lesions. Subjects were included in a prospective analysis if they had at least one follow-up visit. Subjects were followed up to the time of their first recurrence.

\section{RESULTS}

Age, parity, age at first sexual intercourse, HPV infection on Pap smear and history of cigarette smoking did not differ by much between women infected and not infected with HIV (Table 1).

Table 1: Sociodemographic characteristics and potential risk factors for CIN for HIV-positive women and controls (HIV-negative)

\begin{tabular}{|c|c|c|}
\hline $\begin{array}{l}\text { Sociodemographic } \\
\text { characteristics }\end{array}$ & $\begin{array}{l}\text { HIV-positive women } \\
n=15\end{array}$ & $\begin{array}{l}\text { HIV-negative controls } \\
n=21\end{array}$ \\
\hline Mean age \pm SD (years) & $32.7 \pm 8.0$ & $33.2 \pm 8.1$ \\
\hline $\begin{array}{l}\text { Mean age of coitarche } \pm \mathrm{SD} \\
\text { (years) }\end{array}$ & $16.3 \pm 1.9$ & $16.8 \pm 3.0$ \\
\hline Parity (mean) & 2 & 2 \\
\hline$>5$ sexual partners $(\%)$ & $10(48)$ & $9(60)$ \\
\hline Smoke & $1(6.7)$ & $1(4.8)$ \\
\hline Antiretroviral (HAART) $(\%)$ & $3(20)$ & - \\
\hline CD4 count $<200(\%)$ & $3(20)$ & - \\
\hline CD4 count $200-500(\%)$ & $3(20)$ & - \\
\hline Invasive disease (\%) & $1(6.7)$ & $1(4.8)$ \\
\hline HPV infection (\%) & $15(100)$ & $19(90.5)$ \\
\hline $\begin{array}{l}\text { Recurrence of disease after } \\
\text { treatment }(\%)\end{array}$ & $5(26)$ & $1(4.8)$ \\
\hline Died (\%) & $1(6.7)$ & - \\
\hline
\end{tabular}

CIN - cervical intraepithelial neoplasia, SD - standard deviation, HAART highly active antiretroviral therapy

The majority of the patients in each group were asymptomatic at presentation (67\% and $81 \%)$ and cervical disease was discovered by a routine Pap smear. Other presentations are as seen in Table 2. One HIV-positive woman with ab-

Table 2: Gynaecologic presentation of the patients

\begin{tabular}{lcc}
\hline Presentation & $\begin{array}{c}\text { HIV-positive } \\
\text { women (\%) } \\
\mathbf{n}=\mathbf{1 5}\end{array}$ & $\begin{array}{c}\text { HIV-negative } \\
\text { controls (\%) } \\
\mathbf{n}=\mathbf{2 1}\end{array}$ \\
\hline Routine Pap smear & $10(67)$ & $17(81)$ \\
Vaginal discharge & $2(13)$ & $1(4.8)$ \\
Vulval warts & $2(13)$ & $1(4.8)$ \\
Abnormal vaginal bleeding & $1(6)$ & $2(9.5)$ \\
\hline
\end{tabular}

normal vaginal bleeding had invasive disease. Of the HIVnegative women with abnormal vaginal bleeding, one had cervical cancer and the other had CIN 1.

The most common cervical lesion was CIN 1 (60\% and $52 \%$ ) and abnormal Pap smear was the most common presentation for this lesion (62\% and 72\%). The incidence of highgrade lesions was not different between the groups (40\% and $48 \%$ ) [Table 3]. The mean age by CIN types was similar in both groups. 
Table 3: Frequency and types of cervical abnormalities and age distribution

\begin{tabular}{lcccc}
\hline $\begin{array}{l}\text { Cervical } \\
\text { abnormality }\end{array}$ & $\begin{array}{c}\text { HIV-positive (\%) } \\
\mathbf{n}=\mathbf{1 5}\end{array}$ & $\begin{array}{c}\text { Mean } \pm \text { SD } \\
\text { age }\end{array}$ & $\begin{array}{c}\text { HIV-negative (\%) } \\
\mathbf{n = 2 1}\end{array}$ & $\begin{array}{c}\text { Mean } \pm \text { SD } \\
\text { age }\end{array}$ \\
\hline CIN 1 & $9(60)$ & $32 \pm 9.0$ & $11(52)$ & $30.6 \pm 8.6$ \\
CIN 2 & $2(13)$ & $33 \pm 2.6$ & $4(19)$ & $33.6 \pm 4.3$ \\
CIN 3 & $3(20)$ & $38 \pm 9.6$ & $5(24)$ & $39.5 \pm 8.0$ \\
Invasive lesion & $1(7)$ & 34 & $1(5)$ & 36 \\
\hline
\end{tabular}

\section{HIV INFECTION AND CIN}

HIV-positive women were analysed separately in a model that included date of HIV diagnosis to CIN presentation, antiretroviral therapy and CD4 lymphocyte count. The date of diagnosis of HIV was known for 13 of the 15 subjects who had chart review. The mean age at which a diagnosis of HIV was made was $30 \pm 7.9$ years. Eight $(62 \%)$ of the cohort were diagnosed with HIV prior to presentation. The mean time between HIV diagnosis and presentation was $4.2 \pm 2.3$ years. Five $(33.3 \%)$ were diagnosed with HIV at a mean of six months after presentation. The majority of the patients presented within two years of HIV diagnosis with CIN 1 (Table 4).

Table 4: Subjects by cervical intraepithelial neoplasia (CIN) diagnosis at presentation and relationship to HIV diagnosis $(n=13)$

\begin{tabular}{lcccc}
\hline & $\begin{array}{c}\text { Diagnosed with HIV prior } \\
\text { to referral }\end{array}$ & $\begin{array}{c}\text { Diagnosed with HIV after } \\
\text { referral }\end{array}$ \\
\hline $\begin{array}{l}\text { Cervical } \\
\text { abnormality }\end{array}$ & $\begin{array}{c}\text { Number } \\
\text { of } \\
\text { subjects }\end{array}$ & $\begin{array}{c}\text { Time from } \\
\text { diagnosis to } \\
\text { presentation } \\
\text { (years) }\end{array}$ & $\begin{array}{c}\text { Number of } \\
\text { subjects }\end{array}$ & $\begin{array}{c}\text { Time from } \\
\text { diagnosis to } \\
\text { presentation } \\
\text { (years) }\end{array}$ \\
\hline CIN 1 & 4 & $4.5 \pm 2.5$ & 3 & $0.2 \pm 0.2$ \\
CIN 2 & 2 & $3.9 \pm 2.6$ & 1 & 0.6 \\
CIN 3 & 2 & $4.1 \pm 3.7$ & 1 & 1.1 \\
Invasive & & & 1 & \\
\hline
\end{tabular}

Only three (20\%) of the 15 patients were known to be on highly active antiretroviral therapy (HAART). Two patients had mild cervical dysplasia (CIN 1), the other had CIN 3. Most of the patients with low-grade lesions were not on antiretroviral therapy.

The CD4 count was known for six of the subjects. The CD4 count for three women was $<200$ cells $/ \mu \mathrm{L}$; two had CIN 1 and one had CIN 2. For those with CD4 counts of 200500 cells/ $\mu \mathrm{L}$, one subject each had CIN 1, CIN 2 and CIN 3.

The treatment options for both HIV-positive and controls were similar. These consisted mainly of cold coagulation (local ablative therapy) and large loop excision of the transformation zone [LLETZ] (Table 5).

Thirty subjects (11 HIV-positive and 19 HIV-negative) had at least one follow-up Pap smear. The mean follow-up time was 1.7 years. Five (45.5\%) HIV-positive subjects had CIN recurrence (low-grade lesions) following therapy. One patient who had cold coagulation had recurrence of the same lesion in seven months and four patients who had LLETZ
Table 5: Treatment by cervical intraepithelial neoplasia (CIN) and HIV status

\begin{tabular}{lcc}
\hline Treatment & $\begin{array}{c}\text { HIV-positive } \\
\mathbf{n}=\mathbf{1 5}\end{array}$ & $\begin{array}{c}\text { HIV-negative controls } \\
\mathbf{n = 2 0}\end{array}$ \\
\hline Cold coagulation & $4(26.7 \%)$ & $8(38 \%)$ \\
LLETZ & $9(60 \%)$ & $11(52.4 \%)$ \\
Hysterectomy & $2(13.3 \%)$ & $1(4.8 \%)$ \\
\hline
\end{tabular}

LLETZ - large loop excision of the transformation zone

procedure had recurrence within 3-25 months. The rate of CIN recurrence was 66.2 per 100 person years in the HIVpositive women and 3.0 per 100 person years in the control group. The hazards rate ratio for recurrence in subjects with HIV after adjusting for age and CIN stage was 19.1 (95\% CI 4.4, 82.1) [Figure].

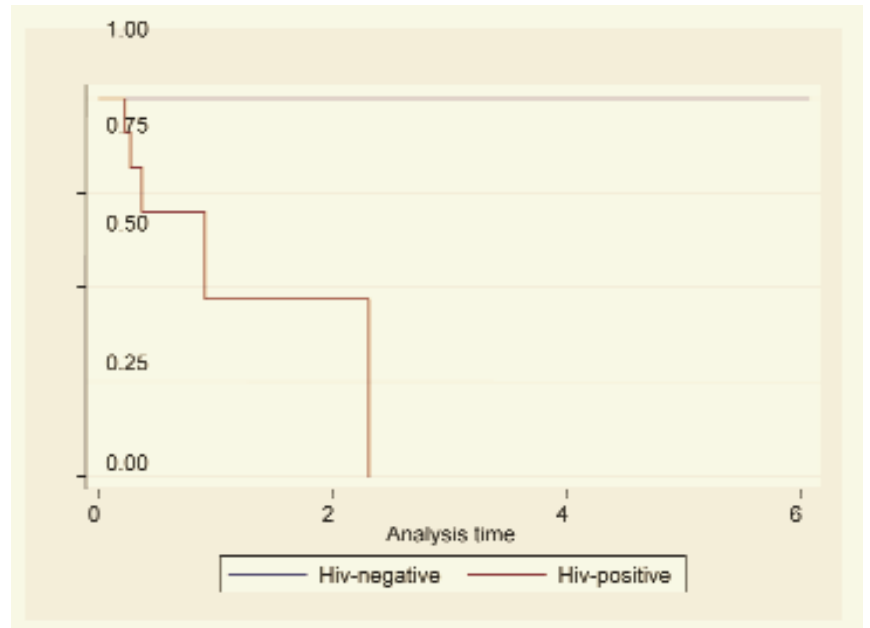

Figure: Kaplan-Meier survival curves of recurrence by HIV status.

The mortality rate for the HIV-positive subjects was $13.3 \%(2 / 15)$. One patient with CIN 3 and a three-year history of HIV infection died two years after treatment. The exact cause of her death was not ascertained from the chart. The second death occurred in a patient who was diagnosed with HIV one year after she was discovered to have invasive cervical cancer. She had radical hysterectomy performed, but died four years after presentation. There were no deaths recorded for the controls during the follow-up period. 


\section{DISCUSSION}

It has been reported that HIV-positive women have as much as a 10-fold increased rate of abnormal cervical cytology, including a wide range of cellular and inflammatory changes, such as hyperkeratosis parakeratosis, trichomonas, herpes, inflammatory atypia, HPV-related changes and varying degrees of cervical neoplasia (4). Higher rates of abnormalities have been demonstrated after seroconversion than before seroconversion. Studies from several centres have shown that women who are immunodeficient from HIV infection have cytological abnormality rates between $30 \%$ and $60 \%$ (5) and Pap smears consistent with dysplasia from $15 \%$ to $40 \%$ (6). In this study, $71 \%$ of the HIV-infected women seen at the clinics had cervical dysplasia. Most studies have consistently demonstrated that the prevalence of these abnormalities increases as immunodeficiency becomes more severe. As a result, the Centers for Disease Control and Prevention (CDC) recommend Pap smear screening in women with HIV every six months (7).

Given the large number of women living with HIV/ AIDS in Jamaica, it is interesting to note that very few patients were referred to the UHWI colposcopy clinic. This could possibly be due to the low rate of Pap smear screening done on these patients. In the present study, the majority of the HIV-positive subjects were seen with cervical dysplasia after a routine Pap smear and the degree of dysplasia was mild, although this presentation was not statistically different from the controls.

There were statistical differences between the groups and associated risk factors for CIN. However, patients who had more sexual partners had more severe dysplasia than those with less sexual partners across the groups and this was independent of HIV status. This relationship between sexual partners and severity of dysplasia correlated with the findings of Bazuaye et al (8). In their study, which looked at lifestyle factors and sexual practices and the development of cervical dysplasia in women with abnormal Pap smear (236) and those without cervical abnormality (102), they found that parity and number of sexual partners were independent risk factors for high-grade cervical dysplasia. In their multivariate analysis, after controlling for age, number of sexual partners remained significant. The present study did not find parity to be a risk factor but this could be related to the sample size. Smoking and early age at first intercourse are associated with the disease in other populations (9). Both the cases and controls had similar rates of HPV infection on Pap smear. Natural history studies examining the biologic behaviour of cervical HPV and CIN strongly suggest that the disease is more aggressive in HIV-positive patients.

The median time of presentation of CIN after HIV diagnosis was similar to the finding of Conley et al (10). In their study, they found a median time of 25 months (range 568 months) to develop cervical lesions after follow-up of HIV subjects twice yearly with a mean follow-up time of 3.2 years.
The present study only found one HIV-positive patient with invasive cervical cancer (stage 1B), who had radical hysterectomy but died four years after diagnosis. The patient with invasive cervical lesion in the control group is still alive after four years of diagnosis. Although much of the data so far have been limited to case reports and single institution studies, it seems apparent that in some HIV-infected women, the disease characteristics may take a more aggressive clinical course (11). In the largest study to date at the SUNYHealth Science Center, Brooklyn in the United States of America, comparing 16 seropositive to 68 seronegative women, significantly more advanced disease was found in the HIV-positive women (11). Half of the seropositive patients presented with stage 3 or 4 diseases, compared with $19 \%$ in seronegative controls. Most importantly, the majority of the patients died of cervical cancer before they died of AIDS and were usually asymptomatic with regard to HIV. In that same study, the median time to death was found to be 10 months in seropositive women compared with 23 months in seronegative patients.

The treatment of CIN was similar for both cases and controls. However, the HIV-positive patients had recurrences compared to one in the controls. Treatment of pre-invasive cervical disease in HIV-positive women is among the most challenging tasks faced by the gynaecologists. Excisional methods are preferred over ablated therapy. Del Priore et al (12) reported that colposcopically directed biopsies may be poor predictors of histology on excisional cone specimens in HIV-seropositive women since $47 \%$ with CIN 2-3 on cone biopsy had only CIN 1 or HPV on punch biopsy compared with only $9 \%$ in HIV-negative patients. Even though some subjects in the present study with CIN were treated by excisional therapy in cases where there were discrepancies between the colposcopy findings and histology of the punch biopsy, the recurrence rate was almost twice as high for those treated by excisional methods than those treated by ablative methods. This is contrary to findings in other populations. In one study, $48 \%$ of HIV-infected women with low-grade CIN developed recurrence compared with $1 \%$ of seronegative women (13). The only confounder in the present study was the CD4 T lymphocyte counts, as $27 \%$ of those with counts less than 200 cells $/ \mathrm{mm}^{3}$ and who had LLETZ procedure had recurrences. Recurrence rate for CIN in HIV-positive women with standard therapies have been reported to be as high as $40 \%$ at one year and $60 \%$ with longer follow-up (13). Wright et al (14) and Del Priore et al (15) reported recurrences of $39 \%$ and $40 \%$, respectively, compared with $9 \%$ and $10 \%$ in seropositive controls. Fruchter et al, at 36 months, reported a $62 \%$ failure rate compared with $18 \%$ in control subjects, and an $87 \%$ failure rate in patients with CD4 less than 200/mm (3).

In response to the high rates of treatment failures for pre-invasive cervical disease in HIV-positive women, the AIDS Clinical Trials Group (ACTG) is investigating novel therapeutic approaches (16). For patients with high-grade 
dysplasia, ACTG recommends the use of topical vaginal fluorouracil cream as maintenance therapy and prophylaxis against recurrent CIN.

The limitations of this study were largely related to the sample size and therefore trends were difficult to pick up. The evaluation of risk factors was limited to the data available in the charts reviewed; a larger cohort of patients and longer follow-up would allow further evaluation of factors related to recurrences and survival.

\section{REFERENCES}

1. Byrne MA, Taylor-Robinson D, Munday PE, Harris JR. The common occurrence of human papillomavirus infection and intraepithelial neoplasia in women infected by HIV. AIDS 1989; 3: 379-82.

2. Centers for Disease Control and Prevention. 1993 revised classification system for HIV infection and expanded surveillance case definition for AIDS among adolescents and adults. MMWR Recomm Rep 1992; 41: $1-19$.

3. Fruchter RG, Maiman M, Sedlis A, Bartley L, Camilien L, Arrastia CD. Multiple recurrences of cervical intraepithelial neoplasia in women with the human immunodeficiency virus. Obstetric Gynecol 1996; 87: 338 44.

4. Provencher D, Valme S, Averette HE, Ganjei P, Donato D, Penalver M et al. HIV status and positive Papanicolaou screening: identification of a high-risk population. Gynecol Oncol 1988; 31: 184-90.

5. Schrager LK, Friedland GH, Maude D. Cervical and vaginal squamous cell abnormalities in women infected with the human immunodeficiency virus. J AIDS 1990; 2: 570-5.

6. Smith JR, Kitchen VS, Bothcherby M, Hepburn M, Wells C, Gor D et al. Is HIV infection associated with an increase in the prevalence of cervical neoplasia? Br J Obstet Gynaecol 1993; 100: 149-53.
7. Centers for Disease Control. Classification system for human Tlymphotropic virus type Ш/lymphadenopathy-associated virus infections. MMWR Morb Mort Wkly Rep 1986; 35: 334-9.

8. Bazuaye PE, Fletcher H, McFarlane-Anderson N. Lifestyle and cervical dysplasia in Jamaica. Int J Gynecol and Obstet 2004; 84: 1757.

9. Canavan TP, Doshi NR. Cervical cancer. Am Fam Physician 2000; 61: 1369-76.

10. Conley LJ, Ellerbrock TV, Bush TJ, Chiasson MA, Sawo D, Wright TC. HIV-1 infection and risk of vulvovaginal and perianal condylomata acuminate and intraepithelial neoplasia: a prospective cohort study. Lancet 2002; 359: 108-13.

11. Maiman M, Fruchter RG, Guy L, Cuthill S, Levine P, Serur E. Human immunodeficiency virus infection and invasive carcinoma. Cancer 1993; 71: 402-6.

12. Del Priore G, Gilmore PR, Maag T, Warshal DP, Cheon TH. Colposcopic biopsies versus loop electrosurgical excision procedure cone histology in human immunodeficiency virus-positive women. J Reprod Med 1996; 41: 653-7.

13. Maiman M, Fruchter RG, Serur E, Levine PA, Arrastia CD, Sedlis A. Recurrent cervical intraepithelial neoplasia in human immunodeficiency virus-seropositive women. Obstet Gynecol 1993; 82: 170-4.

14. Wright T, Koulos, Schnoll F, Swanbeck J, Ellerbrock TV, Chiasson MA et al. Cervical intraepithelial neoplasia in women infected with the human immunodeficiency virus: outcome after loop electrosurgical excision. Gynecol Oncol 1994; 55: 253-8.

15. Del Priore G, Maag T, Bhattacharya M, Garcia PM, Till M, Lurain JR. The value of cervical cytology in HIV-positive women. Gynecol Oncol 1995; 56: 395-8.

16. Krebs HB. Prophylactic topical 5-fluorouracil following treatment of human papillomavirus-associated lesions of the vulva and vagina. Obstet Gynecol 1986; 68: 837-41. 